\title{
Barriers and Drivers for Applying Fish Traceability System in Emerging Market
}

\author{
Elimawaty Rombe, Rahmat Mubaraq, Suryadi Hadi*, Rizka Adriansyah, Gatha Vesakha \\ Department of Management, Faculty of Economics, University of Tadulako \\ Jl. Soekarno Hatta km 9, Tondo, Palu PO Box 94118, Central Sulawesi Province, Indonesia
}

\begin{abstract}
Fish traceability system provides more values for entities to improve their business processes. The philosophy of traceability is that the process is shared along the chain and promote visibility of quality. In this paper, the barriers and drivers are identified and the problem of fish traceability is defined. Five entities examples are analyzed using a critical success factors (CSFs) theoretical framework. The paper offers a framework for managers which provides the basis for developing a fish traceability system. The case analysis identifies diffe rent approaches to fish traceability, highlights the barriers include laws and regulations, coordination, cost, information and infrastructure. Meanwhile, the drivers of applying fish traceability system include seafood fraud risks, sustainability information, expanding market, consumer behavior, and efficiency of operations management. This paper contributes to provide dimensions which can be considered by fishery industry, programmers and government before they plan to build a traceability system.
\end{abstract}

\section{Introduction}

Implementing traceability has been an interesting study for scholars because the behavior of customers has also been shifted to be more concern to the value of the products. Seafood products have complex supply chain and have significant impact on the complexity to provide traceability systems. Some products are changing hands 6 to 10 times before reaching the consumer. Tracing and monitoring for seafood has remained relatively unaffected. However, identifying the first actor in the supply chain is the main issue because the lack of records for all fishing vessels. Most of product records is currently on paper based and mainly reside at distributors and wholesalers level. Therefore, the lack of transparency in the seafood occurs because it has lack of collaboration from upstream side to downstream side.

The smart consumers tend to require more information about products and interested to find out their foods' origins. There are scholars believe that benefit of traceability offers an opportunity for actors in the supply chain to stay competitive. Traceability has also influence to regulation and behavior that are reshaping the food production and consumption landscape ${ }^{1}$. However, traceability may have negative impact on all entities performance if data flows from the upstream to downstream are not accurate ${ }^{2}$. The cost becomes higher since the entities fail to communicate with their customers.

Traceability systems play an important role as monitoring system and provide real time information and faster response for accidents ${ }^{1}$. Consumers are interested to pay a premium price if the food has proper tracking systems because of safety reason ${ }^{3}$. The customers' perception also impacts on the marketing campaign and introduce food safety ${ }^{4}$. In addition, traceability can also help the industry to ensure the halal product and to minimize the risk until the product is on the hand of customers ${ }^{5}$. In other words, the customers will have more benefits because the systems provide history of the product and producers will take an action when they found contamination ${ }^{6}$.

In recent years, scholars have been studied the topic of food safety with different approach. There are several researchers identify that traceability issue is correlate to the food safety. High quality of product is not guaranteed uncontaminated from toxic chemical, undetected pathogenic organisms, or physical hazards ${ }^{7}$. The most of the previous study focus on retailers' perspective and the most popular technology discussed in the systems used RFID ${ }^{1}$. For example, Wang and $\mathrm{Li}^{8}$ found that retailers have more benefits from RFID-enabled traceability system. The last research using RFID as the main focus, Barge et al. and Qian et al. have identified the effectiveness of using RFID to track the food product in various type of food product ${ }^{9-10}$. The previous studies suggest that studies in this area are needed as the perception of customers has been changed. Thus, this paper presents the barriers and drivers of implementing fish traceability system to add the gap of findings in this area of study. This paper offers several points for food industry and programmers which issues are need to consider before building prototype of fish traceability system in the future.

\section{Literature Review}

\subsection{Definition of Traceability}

The definition of traceability is always widespread because traceability is a tool for achieving a number of different goals ${ }^{2}$. According to ISO $8402^{11}$ quality standards, traceability is defined as the ability to track the history, application or location of an entity by identification identified. Whereas in the ISO $9000^{12}$ standard, the definition extends to the ability to trace the history, application or location of what is being considered. The ISO 
guidelines further determine that traceability may refer to the origin of materials and parts, processing history, and distribution and product delivery locations.

Van Dorp ${ }^{13}$ provides a long list of definitions of traceability, indicating that the differences between them come from the different types of activities included and the organizational context in which they are conducted. The Codex Alimentarious Commission (CAC) ${ }^{14}$ defines a shorter definition of traceability as the ability to follow the movement of a food through certain stages of production, processing, and distribution.

Moe proposes an interesting definition for traceability in the batch production industry: he introduces in this definition the notions of chain and internal traceability ${ }^{15}$. Traceability is the ability to track a product batch and its history through the whole, or part, of a production chain from harvest through transport, storage, processing, distribution and sales (hereafter called chain traceability) or internally in one of the steps in the chain for example the production step (hereafter called internal traceability). Olsen and Borit clarify traceability based on ISO definition as the ability to access any or all information related to what is being considered, throughout its entire life cycle, using the identification recorded $^{16}$. Karlsen et al. suggest that traceability is not a product and process of information itself, but a possible tool for finding this information again in the future ${ }^{17}$.

Two types of product traceability can be distinguished. Tracing is the ability, in every point of the supply chain, to find origin and characteristics of a product from one or several given criteria. It is used to find the source of a quality problem ${ }^{18}$. Tracking is the ability, in every point of the supply chain, to find the localization of products from one or several given criteria. It is used in case of product recall ${ }^{18}$. The distinction between these two trace abilities is important. Indeed, an eff ective information system for one of these traceability is not necessarily eff ective for the other.

\subsection{Benefits of Traceability}

Business Benefits of Implementing Traceability Effective traceability practices require disciplined data collection, management and analysis along an industry's complete value chain. As a result, businesses implementing these practices will be more financially and environmentally sustainable. A traceability system should track information such as pricing, origin, quality and quantity to create value for distributors and buyers ${ }^{19}$. Though competition may preclude sharing this information between buyers, it is internally valuable. Sharing information among actors and coordinating the application of traceability have positive impact on quality in food industry value chains ${ }^{5}$. Traceability effectively improves product quality as producers know that buyers will be able to attribute products directly to them and will also know the date of production ${ }^{20}$. Inventory management systems have been proven to reduce overall operating costs for businesses through reduced product recalls, improved tracking and food safety, and risk mitigation ${ }^{1}$.

\section{Research Method}

Case study research to build theory has been the method used in order to understand the barriers and drivers fish traceability in these companies ${ }^{21}$. A series of interviews have been conducted across a range of actors. Theoretical sampling was used to choose cases, with the intention being to select cases representing different actors and therefore enable case comparison across entities in fish supply chain. A framework was developed to give a well-defined focus around which semi-structured interviews could be organized based on literature and previous research. Questions were asked about the type of barriers and drivers which impact on implementing the traceability. The framework was considered tentative and therefore subject to change during the iterative process of case study research. General background information about the actor was also obtained. Data were collected by interviews with key actors along the fish chain and analyzed both within case and cross case to generate and eventually refine theories. The barriers and drivers of implementing traceability was identified by evaluating the internal and external resources of each actor. The description of case study is presented in the next section.

\section{Case Study}

The growth of fish catches in Indonesia in the last five years has experienced a significant increase so that it has a positive impact on the level of fish exports. However, the accuracy of catch-fish data is weak. Thus, it is a critical issue for the fish industry in particular and food in general in Indonesia to recognize where is their fish originated from the beginning to the last consumer dining table. The case data in this paper involve entities in the fish supply chain include fishermen, collectors, fish processing, traders and consumers.

\section{Conclusion}

There are several view point that this study concludes about the possibility to apply traceability from different entities in the fish supply chain. In terms of barriers, the study found that the traceability need a support from internal and external of the chain. In the external point of view, the laws and regulation can play an important role to support the fish chain in terms of standard and safety for the final customer need. Therefore, the government support needs to provide standard which the entities have to apply for the sustainability of the chain. In addition, the infrastructure has a significant impact on the application of fish traceability systems. In the internal side, the cost issue for fish traceability systems should also be discussed among the entities because this system is expensive to operate. In addition to this, the coordination among the chain can also impact on the application because most of the entities act based on their own activity. In other words, the integration between entities in the fish chain is not established. Meanwhile, the drivers of this system include seafood fraud risk, sustainability, expanding market, consumer behavior, efficiency of operations management. Currently, the fish products have not provided

label of origin so that the final customers have not an opportunity to identify the fish product before they purchase. The information flow from the origin to the last customers support the sustainability of the fish supply chain. Furthermore, the data on the label may also add the value of product so that the span of market will be expanded. In the current days, consumers demand the visibility of the product which they will purchase and this open an opportunity for the system to provide additional value for the customers. What is more, the entities gain benefits because the span of control is more efficient in terms of inventory product. Thus, these drivers need to consider by all actors in the fish chain before they plan to build and apply the system in the future. Based on the positive outcome of applying the fish traceability system, entities have to collaborate to provide the system so that the performance of fish supply chain will also be improved.

\section{Acknowledgments:}

The work was supported by Indonesian Ministry of Research and Higher Education under the project of strategic research of national institution (Penelitian Strategis Nasional Institusi) No.281.aa/UN28.2/PL/2018. 


\section{References}

[1] Lijing Zhu, Economic Analysis of Traceability System for Two Level Perishable Food Supply Chain, Sustainability, 9, 682 (2017).

[2] Golan, E., Krissoff, B., Kuchler, F., Calvin, L., Nelson, K., Price, G., Traceability in the US food supply: economic theory and industry studies. Agricultural Economic Report, Iss. 830, No. 3, pp. $1-56$ (2004).

[3] Lu, J., Wu, L., Wang, S., Xu, L., Xu, L., Consumer preference and demand for traceable food attributes. Br. Food J., 118 (2016).

[4] Van Rijswijk, W., Frewer, L.J., Menozzi, D., Faioli, G. Consumer perceptions of traceability: A cross-national comparison of the associated benefits, Food Qual. Preference, 19 (2008)

[5] Khan, S., Haleem, A. Khan, M.I., Abidi, M.H., Al-Ahmari, A., Implementing Traceability Systems in Specific Supply Chain Management (SCM) through Critical Success Factors (CSFs), Sustainability, 10, 204, (2018).

[6] Farooq, U., Tao, W., Alfian, G., Kang, Y.S., Rhee, J., Pedigree Traceability System for the Agricultural Food Supply Chain to Ensure Consumer Health. Sustainability, 8, 839 (2016).

[7] Aung, M.M., Chang, Y.S., Traceability in a food supply chain: Safety and quality perspectives. Food Contr, 39 (2014).

[8] Wang, X.; Li, D. A dynamic product quality evaluation based pricing model for perishable food supply chains. Omega, 40 (2012).

[9] Barge, P., Gay, P., Merlino, V., Tortia, C., Item-level RadioFrequency Identification for the traceability of food products: Application on a dairy product. J. Food Eng, 125 (2014).

[10] Qian, J.P., Yang, X.T., Wu, X.M., Zhao, L., Fan, B.L., Xing, B., A traceability system incorporating 2D barcode and RFID technology for wheat flour mills. Comput. Electron. Agric. (2012).
[11] ISO 8402. Retrived from http://www.scibrid.com/do c/40047151/ISO-8402-1994-ISO-Definitions, (1994).

[12] ISO 9000. Retrieved from http://www.pqmonline.com/assets/files/standards/iso 9000-2005.pdf, (2005).

[13] Van Dorp, K.J., "Tracking and tracing: a structure for development and contemporary practices", Logistics Information Management , Vol. 15 No. 1, pp. 24-33, (2002).

[14] CAC., Codex Procedural Manual (15th ed.), Retrieved from $\mathrm{ftp} / /$ ftp.fao.org/codex/Publications/ProcManua 1s/Manual_15e.pdf, (2005).

[15] Moe, T., Perspectives on traceability in food manufacture, Food Science and Technology, 9 (1998).

[16] Olsen, P., and Borit, M., How to define traceability. Trends in Food Science \& Technology, 29 (2013).

[17] Karlsen, K. M., Olsen, P., \& Donnnelly, K. A., Implementing traceability: practical challenges at a $\mathrm{m}$ ineral water bottling plant, British Food Journal, 11 2(2), (2010).

[18] GENCOD EAN France., La tracabilite' dans les chaı^nes d'approvisionnement: de la strate'gie a' la pratique. GENCOD EAN France member of EAN International, (2001).

[19] Trienekens, J.H., Wognum, P.M., Beulens, A.J.M., van der Vorst, J.G.A.J., Transparency in complex dynamic food supply chains. Adv. Eng. Inform, 26 (2012).

[20] Bosona, T., Gebresenbet, G., Food traceability as an integral part of logistics management in food and agricultural supply chain, Food Control, 33 (2013).

[21] Eisenhardt, K. M., Building theories from case study research. Academy of management review, 14(4) (1989).

Table 1. Barriers of Data Cases

\begin{tabular}{|c|c|c|c|c|c|}
\hline & Fishermen & Collectors & Fish Processing & Traders & Consumers \\
\hline $\begin{array}{l}\text { Laws and } \\
\text { regulations }\end{array}$ & $\begin{array}{l}\text { It becomes an obstacle } \\
\text { and reduce the area of } \\
\text { fish operation }\end{array}$ & $\begin{array}{l}\text { The government havelack of } \\
\text { attention to apply traceability } \\
\text { system }\end{array}$ & $\begin{array}{l}\text { Governmentneed to } \\
\text { publish and control } \\
\text { the regulation }\end{array}$ & $\begin{array}{l}\text { The current policy only } \\
\text { focus on the initial stage } \\
\text { of fish supply chain }\end{array}$ & $\begin{array}{l}\text { There is no regulation so } \\
\text { that poor standard on } \\
\text { available }\end{array}$ \\
\hline Coordination & $\begin{array}{l}\text { It will need a high level } \\
\text { of coordination }\end{array}$ & It is not easy to apply & $\begin{array}{l}\text { The fish supply chain } \\
\text { have complexity }\end{array}$ & $\begin{array}{l}\text { Coordination is one of } \\
\text { the key in fish supply } \\
\text { chain }\end{array}$ & $\begin{array}{l}\text { Put attention on upstream } \\
\text { and downstream side of } \\
\text { the fish chain }\end{array}$ \\
\hline Cost & It needs high budget & Third party need to involve & $\begin{array}{l}\text { It is expensive } \\
\text { because the fish chain } \\
\text { is too complex }\end{array}$ & $\begin{array}{l}\text { The government should } \\
\text { involve in funding the } \\
\text { system }\end{array}$ & $\begin{array}{l}\text { The total cost should be } \\
\text { negotiated among the } \\
\text { actor along the entities or } \\
\text { the government should } \\
\text { provide }\end{array}$ \\
\hline Information & $\begin{array}{l}\text { It takes time to input the } \\
\text { information }\end{array}$ & $\begin{array}{l}\text { We are not understand about } \\
\text { the input process }\end{array}$ & $\begin{array}{l}\text { Data accuracy is } \\
\text { questionable }\end{array}$ & $\begin{array}{l}\text { The complexity of the } \\
\text { chain have a significant } \\
\text { impact on data accuracy }\end{array}$ & $\begin{array}{l}\text { It is compulsory for the } \\
\text { upstreamand } \\
\text { downstream side of the } \\
\text { chain }\end{array}$ \\
\hline Infrastructure & $\begin{array}{l}\text { There is no proper } \\
\text { infrastructure available } \\
\text { for the system }\end{array}$ & Lack of IT res ources & $\begin{array}{l}\text { Several areas of } \\
\text { fishery points have } \\
\text { no IT provides }\end{array}$ & $\begin{array}{l}\text { Entities in the fish supply } \\
\text { chain should have similar } \\
\text { infrastructure }\end{array}$ & $\begin{array}{l}\text { Entities should involve in } \\
\text { collaboration }\end{array}$ \\
\hline
\end{tabular}

Table 2. Drivers of Data Cases

\begin{tabular}{|c|c|c|c|c|c|}
\hline & Fishermen & Collectors & Fish Processing & Traders & Consumers \\
\hline $\begin{array}{l}\text { Seafood fraud } \\
\text { risks }\end{array}$ & $\begin{array}{l}\text { It will reduce illegal } \\
\text { fishing in the future }\end{array}$ & $\begin{array}{l}\text { It will have impact on the } \\
\text { product for the next } \\
\text { entities }\end{array}$ & $\begin{array}{l}\text { It will give us an } \\
\text { opportunity to identify } \\
\text { illegal fishing }\end{array}$ & $\begin{array}{l}\text { It will have a significant } \\
\text { impact on our business }\end{array}$ & $\begin{array}{l}\text { It will protect us from } \\
\text { unsafety food }\end{array}$ \\
\hline Sustainability & $\begin{array}{l}\text { We are the first entities } \\
\text { that providedata }\end{array}$ & $\begin{array}{l}\text { All entities should have } \\
\text { awareness to provide data } \\
\text { accuracy }\end{array}$ & $\begin{array}{l}\text { It will help us to reduce } \\
\text { costs and require proper } \\
\text { training }\end{array}$ & $\begin{array}{l}\text { The system will help us to } \\
\text { manage fish stock }\end{array}$ & $\begin{array}{l}\text { We need full of } \\
\text { information }\end{array}$ \\
\hline $\begin{array}{l}\text { Expanding } \\
\text { market }\end{array}$ & It requires 5 tandards & $\begin{array}{l}\text { The government should } \\
\text { established regulations }\end{array}$ & $\begin{array}{l}\text { All actors should } \\
\text { collaborate }\end{array}$ & It requires trade rules & $\begin{array}{l}\text { All entities should follow } \\
\text { the standard and regulation }\end{array}$ \\
\hline $\begin{array}{l}\text { Consumer } \\
\text { behavior }\end{array}$ & $\begin{array}{l}\text { Improvethe customer } \\
\text { satisfaction }\end{array}$ & $\begin{array}{l}\text { It helps us to verify } \\
\text { sustainability chain }\end{array}$ & $\begin{array}{l}\text { We need to adjust our } \\
\text { business strategy based } \\
\text { on the customer attitudes }\end{array}$ & $\begin{array}{l}\text { Consumer will have a } \\
\text { freedom to choose them }\end{array}$ & $\begin{array}{l}\text { It will give us confidence } \\
\text { to consume the product }\end{array}$ \\
\hline $\begin{array}{l}\text { Efficiency of } \\
\text { operations } \\
\text { management }\end{array}$ & $\begin{array}{l}\text { It will replace the mamual } \\
\text { process and provide better } \\
\text { information }\end{array}$ & $\begin{array}{l}\text { It will help us to support } \\
\text { our bargaining position to } \\
\text { the fish processing or } \\
\text { trader and consumers }\end{array}$ & $\begin{array}{l}\text { Most of the systems will } \\
\text { integrate the process }\end{array}$ & $\begin{array}{l}\text { The fish track system is } \\
\text { user friendly }\end{array}$ & $\begin{array}{l}\text { The product will be } \\
\text { provideda label which } \\
\text { consumers can als o track } \\
\text { fish origin }\end{array}$ \\
\hline
\end{tabular}


